\title{
SOCIAL CONFLICTS FOUND IN CHARLES DICKENS' GREAT EXPECTATIONS
}

By: Ali Fauzi

\begin{abstract}
Literature is the expression of life in the works of beauty, truth, and cannot be separated from feeling, thought, or any activities as part of life. By literature, one can express his knowledge and get entertainment because literature is also defined as simply another way one can experience the world around him through his imagination. Meanwhile, novel as a genre of literature, is a reflection of reality the author writes based on his view. The novelist expresses ideas, or values which the readers can accept. In this research report, the researcher analyzes the novel "Great Expectations" to know better about the conflict happening in it mainly social conflict. It is about sad love and wonderful story of a boy named Pip whose parents died and who was brought up by his elder sister, Mrs. Joe Gargery. He loves a girl named Estella who always disdains him because he is a common and coarse boy. For this, he is eager to be a gentleman and wants to get her love. He has fortune because an escaped convict whom he helped when he was a child by giving some food and a file. The escaped convict whom later known as Provis pays Pip's study in London and becomes a gentleman. That is why, he chooses the title "The Analysis of Social Conflicts in Charles Dickens' Great Expectations".

This research is aimed at finding social conflicts undergone by Pip, Miss. Havisham, Provis and Orlick. Therefore, he formulates statement of the problems 1) What are social conflict undergone by Pip? 2) What are social conflict undergone by Miss. Havisham?, 3) What are Social conflict undergone by Provis? And 4) What are social conflict undergone by Orlick?. The Objectives of this research are: 1) to describe the social conflict undergone by Pip, 2) to describe the social conflict undergone by Miss. Havisham, 3) to describe the social conflict undergone by Provis and 4) to describe the social conflict undergone by Orlick.

The researcher in discussing this problems uses many quotations taken from the Novel Great Expectations, and many references. They are taken in chapter II in form of Review of Related Literature. It looks that this research is Qualitative research by using descriptive text analysis. He uses Phenomenological approach as the basis of discussion. The object is the social conflict undergone by four main characters and the subject is the novel Great Expectations. After being analyzed, he finds that Pip undergoes social conflict with Estella, Mrs. Joe Gargery, Herbert, Orlick, Bentle Drummle and Miss. Havisham. Miss. Havisham experiences social conflict with Estella, Campeyson, and her relatives. Provis has social conflict with Compeyson, Orlick has social conflict with Mrs. Joe and Biddy. In fact, if it is examined closely, the conflicts happen around the problems of love either love relationship between Pip and Estella, Estella and Drummle, Compeyson and Miss. Havisham and Orlick with Biddy.
\end{abstract}

Key words: Social Conflicts, Great Expectations, Charles Dickens. 


\section{A. INTRODUCTION}

Literature is simply another way we can experience the world around us through our imagination and by literature we can express everything in our mind and get knowledge from it ( Jones, 1968: 1). Literature can also be defined as saying of human's aesthetics feeling that uses beautiful language as instrument to express. It means that everyone has art and aesthetic feelings a since one must have experience of life by which one can use it as main material of expressing and understanding art and aesthetics. The aesthetics feeling can be distributed through some ways. Nevertheless, good literature is not only because of its language which is full of rhythm but also should be looked from all parts, such as theme, message, structure, and values which contain of thought and feeling. Literature was something worth saying and something well said (Graham Little, 1963: 3). In literature, the author usually applies truth, facts, and style to the basic emotion of man, the emotions of all men may be in form of fear, anger, disgust, pain, hope, joy and sorrow. In it too the author will choose his characters to behave in certain way because he accepts truth and knows certain facts. Literature covers drama, poetry, short story and novel and as genre each of it has its own structure, and characteristics.

A novel is part of literary work written in prose telling a long story in which it includes ranges of setting, characters, conflicts, and present theme. It may tell all aspects of life and activities of someone from children up to adult. A novel is the author's expression of ideas, opinions, and evaluation of life. It also contains thoughts, problems, conflicts, values and whole portray of life. A truth in novel is not necessarily needed as truth in fact, but it must show something that seems real to all 
of us. A novel is a picture of life and manner and of the time in which it is written (Wellek and Warren, 1990: 282). It means that o novel as a creative result of literary work usually serves everything truly available in the world in form of imaginative description of the fact. Therefore, a novel is a result contemplation of real life in imaginative behavior of life in certain time.

In the novel, the novelist expresses ideas or values that the readers can accept. He also creates a completely imagined world through description, dialogues and explores basic human and basic feelings as well as human issues deeply. Therefore it will give readers information in detail mainly information of plot, setting, theme, conflict, character and characterization. As a part of the story elements, conflict especially social conflicts is extra important in the novel. It tells all kind of conflicts between one person and another and it makes the story more alive as it is seen in Great Expectations written by Charles Dickens. Great Expectation is a sad and wonderful love story of a boy called Pip whose parents are dead and who is brought up by his sister. He loves the girl who is always disdainful to him because he is a boy coming from the poor family. Because of this, he wants to be a gentleman and hopes to get her love. When he was a child, he helped an escaped convict by giving some food and a file to him. Because of his kind, the convict helps him by giving him some money through his lawyer and Pip must go to London to study and reach his desire. Pip does not know his real benefactor even he assumes that his benefactor is Miss Havisham.

Through the strong struggle of life to get his expectation, the story is filled with some social conflicts either with the girl he love, Miss Havisham, the convict 
and other people around him and even it is said that this story is dominated by social conflicts. Therefore, the researcher chooses the title "Social Conflicts Found in Charles Dickens' Great Expectations" as the main discussion in this research report. He chooses this title because of several reasons that is the researcher wants to understand the content of the novel especially social conflicts that happen in this story, he wants to know more about literature particularly novel and he wants to find something important in this novel as the additional reading material for the ones interested in it.

Great Expectations is a long story written in prose. In the novel, the characters usually play like people in the fact and the setting of the story usually also real. According to Wellek and Warren (1990: 282), novel is the picture of life and manner, and of the time in which it is written. It can be said that novel as a creative result of literary work which usually serve everything truly that available in the world in form of imaginative description of the fact. Exactly, a novel is the result of fiction or real life in imagination behaviors of life in certain time. It is a form of literature that is also called fiction. Fiction is built up by numbers of elements, every element has relation with others, such as character, conflict, point of view, and plot. Abrams states that novel is characterized as the fiction attempt to give the effect to realism by representing complex characters with mixed motives who are rooted in a social class, operate in a highly developed social the events in the fact deal with social structure or culture of society and describes how the characters in the novel play and relate to others. 
Abrams in this respect classifies the novel into three categories. The first is sociological novel- a novel which emphasizes the influence of social and economical conditions on characters and events and often embodies an implicit or explicit discussion recommending social reform (1957: 113). The second is regional novel- a novel which emphasizes the setting, speech, and customs of particular and locality; it is not merely as local color but as important condition affecting the temperament of the characters, their ways of thinking, feelings, and action. The three is historical novel- a novel which takes its setting and some of its characters and events are elaborately developed and as the important element of the central narrative.

This research is a qualitative research using text analysis. It means that the researcher analyzes the novel and then describes the important points in the text as the material of analysis. Bogdan and Biklen (1982) state that qualitative research has characteristics: 1) using natural setting as the source of direct data and the researcher as the main instrument, 2) attending to descriptive type, 3) preferring the process to the result, 4) analyzing the data inductively, and 5) emphasizing the meaning. Qualitative research design contains a number of activities in well-arranged and planned and he does not use numbers and calculation to process the data but he just describes his finding based on the quotation taken from the object. Moleong (1991: 236) explains that research design is an effort to plan and find all possible thing and requirements the researcher needs in the research. It means that the researcher must formulate all possible things that may happen before and during the research. He formulates a theorical concept which he will use as the basis of his analysis and to find the way to answer the problem found in the research. 
While, the approach in this research is phenomenological approach in which he observe the phenomena happening in the story based on his point of view. Arifin (1994: 46-47) states that in phenomenological approach, the researcher tries to find and interpret fact and cause of something based on the available phenomena and the researcher's own view although it is subjective. So, the researcher analyzes the data based on his understanding on the conflicts particularly social conflicts in the novel. Therefore, the appropriate method used is descriptive text analysis which means that the researcher reads and analyzes the text of the novel, finds social conflicts and then describes them in detail. Meanwhile the instrument of this research is the researcher himself. Moleong (1991: 4-5) states that the characteristics of qualitative research is that human being himself whose function as the key instrument, the data are analyzed inductively, emphasizing on the process more than the result, using focus to limit discussion, determining certain criteria of data, using moment design and discuss the result of research seriously. It means that the researcher of this research becomes the key instrument to find and process the data besides words, phrases, clauses and sentences.

In this research, data are in form of words, phrases, clauses and sentences in the novel Great Expectation leading to social conflicts. Having found and identified social conflicts presented through those things, the researcher tries to describe them and prove the rightness of his assumption by putting sentences to be references in quotation. Meanwhile, the source of data are from literary work books and the related ones as it is stated by Arikunto (1989: 102) that source of data in research refers to where the data taken. Therefore, it is clear that the source of data is the result of deep 
observation and understanding on the novel Great Expectations as a primary data. Besides the primary data, the researcher takes the secondary data in form of the references from related books to get the experts' opinions.

In collecting the data, the researcher does many steps of research like reading the novel, analyzing it shortly, identifying it, and concepting as well as collecting it in raw material. The researcher reads and analyzes the novel Great Expectation from beginning to the end to understand the content of the story deeply. After understanding it especially the conflicts-social conflicts, he then identifies the data in form of signs, sketches and codes. As soon as he does the step, he then concepts and collect them in raw material concept.

After he collects the data which are in form of words, phrases, clauses and sentences put in the raw concept, he then analyzes them part by part in detail to find the real data. Since it is qualitative research, so he analyzes the data inductively. It is in accordance with the opinion of Bogdan and Biklen (1982) that qualitative research has characteristic; 1) using natural setting as the source of direct basis, and researcher as the key instrument, 2) attending to descriptive type, 3) preferring the process to the result, 4) analyzing the data inductively and 5) emphasizing the meaning. It means that the researcher draws conclusion from his own opinion on the discussion and then describes his finding based on his view, the text strengthened by the quotation from the text and from other related reference. 


\section{B. RESEARCH DISCUSSION}

\section{Research Finding}

\section{a. Social Conflict Undergone by Pip}

Pip is the main character in the story. He undergoes social conflicts with other characters in the story.

\section{1). Social Conflict Between Pip and Estella}

Pip came to Miss Havisham's house and met Estella. It looked that she did not like him because he came from the common family and considered as coarse boy. She was always scornful him. It can be seen in the following quotation.

"Through she called me boy so often and so carelessly, she was of about my own age. She seemed much older than I, of course, being a girl, and beautiful and self-possessed, and she was a scornful of me as if she had been one and twenty and a queen" (Great Expectations: 31).

The quotation above shows that Estella and Pip had conflict. She considered that Pip was common and coarse boy. So, she looked Pip one eye. The social conflicts between them still continued when they played card. Estella always insulted and trifled him because she was always the winner.

"He calls the knaves, Jacks, this boy!" said Estella with disdain before our first game was out. "And what coarse hands he has! And what thick boots!. She won the game, and I dealt, I misdealt, as was only natural, when I knew she was lying in wait for me to do wrong, and she called me a stupid, clumsy, laboring boy" (Great Expectations: 34).

The researcher is able to identify that Estella did not like Pip and she always insults him. Pip fells disappointed and six days later, Pip came back to Miss. Havisham's house to play. At this time, the social conflict between them continues. Estella asked Pip about what he thought about her but Pip did not want to tell it so it made Estella angry. It is seen in the following quotation. 
"I had never thought of being ashamed of my hands before, but I began to consider them rather a bad pair. Her contempt was so strong that is become infectious and I caught. Her eyes flashed with anger when she asked the last question, and she slapped my eyes with such force as she had, when I answered it.

"Now?" said she. "You little coarse monster, what do you think of me now?" "I shall not tell you" (Great Expectations: 40).

For a long time Pip were in London to study and to be a gentleman in order that Estella did not scorn him again and looked him as a man. Besides them, he wanted to get Estella's love. However, when Pip told her if he loved her, she refused his love. That is why, Pip was hurt of it.

"You must know," said Estella, "that I have no heart, no sympathy, no sentiment."

I took the liberty to doubt that, and said there could be no such beauty without a Heart.

"I am serious," said Estella, "if we are to be thrown much together, you had better

Believe that it at once. Let us make one more round of the garden, and then go in. $81)$.

Some! You shall not shed tears for my cruelty today." (Great Expectations,

The next social conflict between Pip and Estella happened when Drummle said that he accompanied Estella to drink and to dance. Pip was very jealous and angry. He went to meet Estella to know whether it was true or not. favour

"I cannot express what pain it gave me to think that Estella should show any

To such a contemptible and clumsy fellow."

"Indeed, that is the very question I want to ask you, Said I,

"For he has been hovering about you all night." (Great Expectations, 103)

Pip's anger still continued when he knew that Estella and Drummle dined and rode horse together on other day. Pip asked Estella to know why she did it, Pip was 
also very surprised and hurt when Estella said that she wanted to marry Drummle.

Knoeing this Pip was very disappointed, he had broken heart.

"Then I asked her whether it was true that she encouraged Bentle Drummle, that

She rode out with him, and that he was to dine her that very day."

"She seemed a little surprised that I should know it, but replied, "quite true."

"You cannot love him, Estella?"

"She looked toward Miss. Havisham, and considered for a moment, with her work him."

In her hands. The she said, "Why not tell you the truth? I am going to marry

" I am going", she said in a gentle voice, "to be married to him. The preparations

For my marriage are being made, and I shall be married soon."

"O... Estella!" I answered, as my bitter tears fell fast on her hands. "How can i

See you Drummle's wife?' (Great Expectations, 117).

\section{2). Social Conflict Between Pip and Mrs. Joe Gargery}

Mrs. Joe is Pip's sister. She is Mr. Joe's wife. After their patents died, Pip lived with her. The social conflict happened when Pip was a child. She was angry because Pip always went to the Churchyard where their parents were buried. Mrs. Joe was very angry and worry when Pip was not at home. She disliked Pip to go to the Churchyard and cried for them.

"My sister, throwing the door wide open, and finding on obstruction behind it, Immediately guessed the cause, and applied the stick to me."

"Where have you been you young monkey?" said Mrs. Joe, stamping her foot. "Tell me directly what you have been doing to wear me away with fright and Worry."

"I have only been to churchyard", said I, crying and rubbing myself." "Churchyard!"repeated my sister." If it was not for me you'd have been to the Churchyard long ago, and stayed there."(Great Expectations, 12). 


\section{3). Social Conflict Between Pip and Herbert}

The social conflict between Pip and Herbert happened when they met firstly at Miss. Havisham's house. Pip was a common and labouring boy whereas Herbert was the pale young man with red eyelids, and light hair. Herbert asked Pip to fight because he thought that he was stronger than him. But when Pip hit him, he fell down. He was shy and lose. Pip was the winner in the duel.

"Come and fight," said the pale young gentleman.

What could I do but follow him? His manner was so final, and I was so ashtonished

That I followed where he led, as I had been under a spell.

"Stop a minute through," he said, I ought to give you reason for fighting, too. There another

It is!" in a most irritating manner he instantly slapped his hands against one

Flung one of his legs up behind him, pulled my hair, dipped his head, and butted it

Into my stomach.

"I hit out of him, and was going to hit out again when he began dancing backward

And forwards and said, "Come to the ground." Therefore, I followed him to the end

Of the garden."

"But, to my surprised, as soon as I hit him he fell down on his back, and lay

Looking up at me with his nose bleeding." (Great Expectations, 43-44)

\section{4). Social Conflict Between Pip and Orlick}

Orlick was antagonist character. The first social conflict between Pip and Orlick happened when Pip became an apprentice of Mr. Joe. Orlick did not like Pip because he had assumed that Pip displaced him as Mr. Joe's workman.

"He has no liking for me, and when I became joe's apprentice he liked me still less, thinking that I should displace him." (Great Expectations, 50) 
The second conflict between Pip and Orlick happened when Pip asked Joe to give him a half-holiday because he wanted to visit Miss. Havisham. Orlick was envious and asked Joe to give him a half-holiday like Pip.

"Now, master! Surely you are not going to favour only one of us. If young Pip has a half-holiday, do as much for old Orlick. (He always spoke to himself as old Orlick).

"Why, what'll you do with a half holiday," "what 'll I do with it? What will he Do with it? I'll do as much with it as him." Said Orlick.

"As to Pip, he's going up to town," said Joe.

"Well, then, as to old Orlick, he's going to town," retorted the workman."

Two can go up-town." (Great Expectations, 51)

The hostility between Pip and Orlick had not finished yet. Iy continued when Pip knew that Orlick admired Biddy. Pip disliked it, he had wished that he would love her because she was kind. Orlick also disliked If Pip had a closed relationship with Biddy. Although Pip lived in London, the Social conflict between him and Orlick still continued. It Looked that Orlick Hated Pip very much. He had assumption that Pip Always obstructed him to love Biddy. He always tried to get Biddy's love but Biddy did not like him. Orlick entrapped Pip; he wanted to kill Pip in order to get Biddy.

"I was very indeed upon old Orlick daring to admire her, as hot as if it were An insult to me, I kept an eye on him after that night,"(Great Expectations, 58)

"Unbind me. Let me go!"

"Ah," he returned, "I'll let you go. I'll let you go to the moon; I'll let you go To the stars. All in a good time"

He sat shaking his head at me, then he put his hand into the corner and his side,

And took up the gun"

"Do you know this?"said he pointing the gun at me."Do you know where you saw it before?"Speak, wolf!"

"Yes," I answered.

You did that. And would be enough, without more. How dared you come between me and a young woman I liked? 
"I am going to have your life. I won't have a rag of you, I won't have a bone of you, left on earth, and I"ll put you body in the burning film." Great Expectations, 129-130)

\section{5). Social Conflict Between Pip and Bentle Drummle}

. The social conflict between Pip and Drummle happened because Drummle loved Estella. He always told Pip about him and Estella. It made Pip jealous and angry. Pip thought why Estella drank with Drummle. Seeing this, Pip was ready to fight with Drummle.

"I thought I saw Bentley look mockingly at me in ugly way. Presently he called Upon the company to drink to the health of Estella."

"This insolence filled me with rage; I called him an impudent fellow for daring readiness

To propose a lady of whom he knew nothing nothing, and I expressed my

To fight a duel with him.

"I epressed my readiness to fight a duel with him" (Great Expectations, 102)

Pip went to Miss. Havisham's house when he was in the Blue Boar and saw Drummle. They disliked each other. Drummle always tried to make Pip jealous. He always told about him and Estella and it made Pip angry.

"When the coach drove up the Blue Boar, I saw Drummle come out. It was poison

Ous to me to see him in the town, for I very well knew why he had come here.

"Then Drummle glanced at me, with an insolent triumph on his face me to the Heart. It was a relief when he was gone.” (Great Expectations, 115)

\section{6). Social Conflict Between Pip and Miss. Havisham}

Pip and Miss. Havisham had conflict when he knew that his real benefactor was Provis not her. Pip formerly was sure that his benefactor was her and felt that he had to thank her. After knowing that she was not his benefactor, he was very 
disappointed on her. Miss Havisham was also angry with him because she did not feel to let him thought that she was his benefactor.

"I told Miss. Havisham that I had found out who my benefactor was and she admitted let me on when I felt into the mistake of thinking that, she was my patroness."

"What that kind?" I said

"Who am I, I cried Miss. Havisham, striking her stick upon the floor and flashing suddenly into anger, "who am I, for God's sake, that I should be kind?" (Great Expectations, 115)

\section{7). Social Conflict Between Miss Havisham and Estella}

Miss. Havisham was angry because Estella said that she was tired to do what she wanted that was to revenge to every man. Estella felt that her freedom was taken by Miss Havisham. Estella wanted to love someone without hurting and entrapping him. But Miss Havisham was angry with her and said that she gave everything to her. She claimed that Estella was ungrateful person because she had given her everything but Estella thought that she had taken her life.

"Speak the truth, you ungrateful person!" cried Miss. Havisham, passionately striking her stick upon the floor. "You are tired of me."

"You stock and stone!" exclaimed Miss. Havisham, "You cold, cold heart!"

"What!" said Estella? "Do you blame for being cold? You?"

"Are you not?" was the fierce reply.

"You should know." Said Estella. "I am what you have made me. Take all the

Praise; take all the blame; take all the success; take all the failure; in short, take me."

"Oh, look at her, look at her!" cried Miss. Havisham bitterly, look at her, so hard and thankless." On the hearth where she was brought up! Where I took of into this wretched breast when lavished years of tenderness upon her!"

"Mother by adoption, I have said that I owe everything to you. All I possess is freely yours. All that you have given me is at your command to have again. Beyond that, I have nothing. And if you ask me to give you what you never gave me, my gratitude and duty cannot do impossibilityes." (Great Expectations, 100). 


\section{8). Social Conflict Between Miss. Havisham and Compeyson}

Compeyson made Miss. Havisham's heart hurt. He did not come their wedding party when the guests had been waiting for him and she had worn her bridal. It looked that Compeyson just wanted her money not herself. He pretended to love Miss. Havisham. Miss. Havisham was very disappointed and because of it she hated and revenged her hurt to every man.

"Then there appeared on the scene a man who made love to Miss. Havisham. He pursued her closely, and she passionately loved him. He took advantage of her." The marriage day was fixed, but not the bridegroom. He wrote a letter. "Which she received, I struck in, "When she was dressing for her marriage." "Compeyson is the man who pretended to be Miss. Havisham's love". (Great Expectations, 71).

\section{9). Social Conflict Between Miss. Havisham and Herbert}

The relation between Miss. Havisham and her relative did not run well. In front of her, they showed sweet faces but behind her they hoped she would die soon in order that they could inherited her money. Miss. Havisham knew that they just wanted her money. Her relatives were not rich like her. They were poor and cunning. Besides them, there was another relative, Herbert's father. His name was Mr. Matthew Pocket. He had social conflict not because of her money but because he reminded her that Compeyson was not good person. He left her and he just wanted her money. She was angry with him and ordered him to go out of her house and he had never come again.

"But they did not deceive Miss. Havisham. She knew that all their expressions of affection were false, and that they only came after her money which they hoped to inherit at her death. In return she ridiculed their greed and loaded those with insults which they dared not openly recent."She took the first 
opportunity of angrily ordering my father out of house." (Great Expectations, 42 and 71).

\section{0). Social Conflict Between Provis and Compeyson}

Provis and Compeyson had social conflict. When Provis escaped from jail, he met Compeyson in the marshes. Compeyson and Provis was dueling in the ditch. Compeyson beated him and he shouted that there was an escaped convict. Because of his shouting, the soldiers heard and caught him. Provis and Compeyson contradict each other. Compeyson tried to make him right and made Provis false in front of the Sergeant. He said that Provis would kill him.

"As we came nearer to the shouting, we could hear one voice calling "Murder!" and another, "convict". Runway!" Guard! This way for runway convict. "Then both voices would seen to be stifled in a struggle, and then would break out again"

"Take notice, guard-he tried to murder me," were his first words. "Both were bleeding and panting and cursing and struggling; but of course I knew them both directly."

"Mind!" said my convict, wiping blood from his face with fingers. "I took him! I give him up to you! Mind that!" The other convict bruised and torn all over.

"Tried to murder him?" said my convict, disdainfully.

"Try, and not do it?" I took him, and give him up; that's what I said.

The other pne still gasped, "He tried-he tried-to murder me. Bear-bear witness."

(Great Expectations, 21 and 23)

The other conflicts between Provis and Compeyson happened before they become prisoner. Provis met Compeyson and asked him to be his partner in his business. Provis agreed and he did not know that he was entrapped by Compeyson. It looked that Compeyson was very cruel. Provis hated him very much. Provis was angry when the judge decided that Provis should be put in jail longer than Compoeyson. 
"He persuaded me to go partner with him in his business of swindling, forging, stolen bank-note passing, and such like. All sorts of traps as he could set with his head, and let another man in for, were Compeuson's business. He'd no more heart than an iron, he was as cold as death, and he was cunning as the devil."

"We soon get busy, and he got me into such nets as made me his slave. I always ib debt to him, always under his thumb, always working for him, always getting into danger. At least we were both commited on a charge of circulating stolen bank-notes, and there were other charge behind."

"The Jury recommended Compeyson to mercy an account of good character and bad company, and giving up all the information he could against me. He was sentenced to seven years imprisonment, and I to fourteen." (Great Expectations, 113).

\section{1). Social Conflict Between Orlick and Mrs. Joe}

Mrs. Joe was very upset when orlick disdained her. This conflict began when

Orlick asked Joe to give him a half-holiday like Pip. Mr. Joe gave him but Mrs. Joe came and said that if she became his master, she would not give him. Orlick defected and disdained her. Since then, Mrs. Joe was angry and hated Orlick. He hurt her because he disdained her in front of her husband; therefore, she hated Orlick very much.

"You'd be everybody's master; if you could." Retorted Orlick.

"I'd be a match for all fools and all rogues."

Returned my sister, beginning to work herself into a mighty rage.

"You're a foul woman, mother gargery." Growled Orlick.

"Let her alone, will you?" said Joe.

"What did you say? Cried my sister, beginning to scream.

"What did you say? What did that fellow Orlick say to me, Pip? What did he call me, with my husband standing by? Oh!oh!oh! What was the name he gave me before the base man who swore to defend me? Oh! Hold me! Oh!

(Great Expectations, 51) 


\section{2). Social Conflict Between Orlick and Biddy}

Biddy felt that Orlick liked her but she did not like him and even she hated him. She knew that Orlick was an evil man, so she hated and became afraid if he liked her. Biddy knew that Orlick fell in love with her from his eyes when he was looking at her.

"Biddy was much against his going with said to me in a whisper.

"Don't let him come; I don't like his."

"As I did not like him either, I took the liberty of saying that we thanked him, but we did not want seeing home. He received that piece of information with a yell of slaughter, and dropped back, but came idly after us at a little distance. I asked Biddy why she did not like him."

"Oh!" she replied. "Because I - I am afraid he likes me."

"Did he ever tell you he liked you?" I asked angrily.

"No," said Biddy, glancing over her shoulder, "he never told me so, but he glances at me whenever he can catch my eye."

(Great Expectations, 58)

\section{Research Discussion}

\section{a). Social Conflict Undergone by Pip}

Jones, Jr (1968: 82) defines that the author describes about position of two people or more. For instance, the main character must be brave against other people to carry on his life. He involved in complex conflict, against outside forces. Pip as the major character has complex social conflict with other characters. He has social conflict with Estella, Mrs. Joe, Herbert, Miss. Havisham, Drummle, and Orlick. Pip undergoes conflict with Estella since he was a child even when he has been a gentle man. Estella always disdains and looks pip down. Nevertheless, Pip admires her and for this reason he has desire to be a gentleman and hopes that she would receive his love. However, he feels disappointed because Estella still refuses him even though he has been a gentleman, even she marries Drummle. 
Mrs. Joe, Pip's sister, brings Pip up after their parents die. Pip underwent conflict with his sister when he was a child. She was often angry with him and hit him with stick because he always went to the Churchyard where their parents were buried. Pip is in conflict against Herbert when they meet et the first time. Herbert asked Pip to fight him because he thought he was stronger than Pip. However, he felt down on the ground when Pip fight him. Meanwhile, Orlick as an antagonist character also undergoes conflict with Pip. It began when Pip became an apprentice of Mr. Joe. He considered that Pip displaced him as Mr. Joe's worker. Besides this, he was also jealous because he thought Pip destruct him to love Biddy. Even he entraps and wants to kill Pip. Pip said to Miss. Havisham that she was lied him and it made her angry. Pip assumed that she was his benefactor and when he knew that his real patroness was Provis not Miss. Havisham. This causes the conflict between Pip and Miss. Havisham.

\section{b). Social Conflict undergone by Miss. Havisham}

Miss Havisham has conflict with Estella. It happened when Estella said that she was tired to do her revenge to the men. Moreover, she considered Estella as ungrateful person. She revenged to the men because she was ever broken hearte. The man who will marry her run away after getting her money. Besides having conflict with Estella, she also has conflict with her relatives. It because they were cunning and hope that she would die soon, so they can inherit her wealth. 


\section{c). Social Conflict Undergone by Provis}

Provis is Pip's benefactor. He has conflioct with Compeyson. It happened when he met Compeyson and became his partner of business. He did not know that Compeyson just lied and entrapped him. Even when they are in jail, Provis is punished longer than him.

\section{d). Social Conflict Undergone by Orlick}

As an antagonist character not only has conflict with Pip but also has conflict with Mrs. Joe and Biddy. Mrs. Joe hated him very much because he disdained her in front of her husband. He also has conflict with Biddy. He loved her but she did not love him even she hated him very much.

\section{CONCLUSION}

Pip as the major character has complex social conflicts with other characters in this story. He has conflict with Estella since he was a child until adult. Estella dislikes Pip because he was common and coarse boy. She always disdained and looked him down. Nevertheless, Pip admired her and for the reason he desired to be a gentleman and hoped that she would receive his love. He felt disappointed because Estella still refused him even though he had become a gentleman and even she married Drummle. Pip also underwent conflict with Drummle. Drummle loved Estella and he always told Pip that he admired her. It made Pip jealous and angry. This made Pip and Drummle disliked each other. 
Mrs. Joe, Pip's sister was always angry with him because he always went to the Churchyard to see their parents' grave. She was angry and said if it was not because of her, Pip did not have patron. In the Churchyard Pip met an escaped convict and helped him by giving some food and a file. Because of Pip's kindness, Pip did not realize that the convict then became his benefactor and made him able to reach his expectations to be a gentleman and studied in London. Formerly, Pip was sure that his patron was Miss. Havisham but in fact he was Mr. Provis the one he helped before. This made Pip angry with Miss. Havisham and considered she lied him.

Pip and Herbert at first meeting has conflict. Herbert asked pip to duel with him because he considered that he was stronger than Pip. Nevertheless, Herbert was defeated by Pip. Orlick had also social conflict with Pip. Orlick did not like Pip when Pip became an apprentice of Mr. Joe. Orlick thought that Pip displaced him. He was also jealous and considered that Pip destructed him to love Biddy. Even, he entrapped and wanted to kill Pip. Orlick had also conflict with Mrs. Joe and Biddy. He disdained her and made her angry even he hit her until she laid at bed for a long time. Orlick loved Biddy and always showed his love to her but Biddy did not accepted it even she aws afraid and hated him.

Miss. Havisham was angry with Estella because Estella said that she had been tired to follow her instruction to take revenge to everyman. Miss. Havisham considered Estella as ungrateful person because she had brought her up. Miss. Havisham asked Estella to flatter everyman because she supposed that everyman was bad. She hated men because she was hurted by Compeyson who did not marry her and took her money instead. Miss. Havisham's relatives also wanted her money. 
They were cunning and hoped that she would die soon so that they could inherit her wealth. Besides having conflict with Miss. Havisham, Compeyson had also conflict with Provis. He entrapped Provis to do dirty work and made Provis jailed longer than him.

\section{BIBLIOGRAPHY}

Abrams, M.H. 1957. A Glossary of Literary Term. USA: Holt, Rinehart and Winstons, Inc.

Arifin, Imron. 1994. Penelitian Kualitatif dalam Ilmu-Ilmu Sosial dan Keagamaan. Malang: Kalimasada.

Biogdan, Rc and Biklen Sk. 1990. Riset Kualitatif untuk Pendidikan: Pengantar Ke Teori dan Metode. Alih bahasa oleh Munandir. Jakarta: Pusat Bahasa Universitas untuk Peningkatan dan Pengembangan Instruksional Universitas Terbuka.

Dickens, Charles. 1950. Great Expectations. Hongkong” Longman Group.

Hornby, AS. 1980. Oxford Advanced learner's Dictionary of Current English. London: The English language Book Society and University Press.

Jones, Edward, H. 1968. Outline of Literature: Short Stories, Novels, and Poems. New York: The Macmillan Company.

Kennedy, X. J. 1983. Literature: An Introduction to Fiction, Poetry and Drama. Toronto: Little Company.

Kenney, William. 1996. How To Analyze Fiction. New York: Monarch Press.

Little, Graham. 1966. Approach to Literature: An Introduction to Critical Study of Content and Method in Writing. Sidney: Science Press.

Moleong, Lexy. 1996. Methodology Penelitian Kualitatif. Bandung: Remaja Rosda Karya.

Perrine, Laurence. 1974. Literature: Structure, Sound, and Sense. New York: Harcourt Brace Jovanovich Inc. 
Suharsimi, Arikunto. 1989. Prosedur Penelitian Suatu Pendekatan Praktek. Jakarta: Rineka Cipta.

Sumardjo, Jakob and Saini KM. 1988. Apresiasi Kesusastraan. Jakarta: PT. Gramedia.

Wellek, Rene and Austine Warren. 1989. Teori Kesusastraan. Jakarta: Gramedia Pustaka Utama. 